\title{
Pathogenic Variability of Angular Leaf Spot Disease of Common Bean in Western Kenya
}

\author{
Robert Kiptabut Leitich $^{1, ~}{ }^{*}$, D. O. Omayio ${ }^{1}$, B. Mukoye ${ }^{1}$, B. C. Mangeni ${ }^{1}$, D. W. Wosula ${ }^{1}$, \\ W. Arinaitwe' ${ }^{2}$, R. M. Otsyula ${ }^{3}$, H. K. Were', M. M. Abang ${ }^{4}$ \\ ${ }^{1}$ Biological Sciences Department, Masinde Muliro University of Science and Technology (MMUST), Kakamega, Kenya \\ ${ }^{2}$ International Centre for Tropical Agriculture (CIAT), Kawanda, Uganda \\ ${ }^{3}$ Kenya Agricultural and Livestock Research Organisation (KALRO), Kakamega, Kenya \\ ${ }^{4}$ Food and Agriculture Organisation (FAO) of the United Nations, Addis Ababa, Ethiopia
}

\section{Email address:}

kipta2012@gmail.com (R. K. Leitich)

${ }^{*}$ Corresponding author

\section{To cite this article:}

Robert Kiptabut Leitich, D. O. Omayio, B. Mukoye, B. C. Mangeni, D. W. Wosula, R. M. Otsyula, H. K. Were, M. M. Abang. Pathogenic Variability of Angular Leaf Spot Disease of Common Bean in Western Kenya. International Journal of Applied Agricultural Sciences. Vol. 2, No. 6, 2016, pp. 92-98. doi: 10.11648/j.jjaas.20160206.13

Received: September 29, 2016; Accepted: October 20, 2016; Published: November 8, 2016

\begin{abstract}
Common bean (Phaseolus vulgaris L.) is the most important legume and is second only to maize as a food crop in Kenya. Despite its importance, bean productivity is declining in western Kenya due to several biotic and abiotic constraints including several fungal diseases. Among these diseases, angular leaf spot (Phaeoisariopsis griseola (Sacc.) is one of the most damaging and widely distributed diseases of common bean, causing yield losses as high as $80 \%$. Furthermore, the problem is compounded by limited information on pathogen distribution and variability in western Kenya hindering breeding for angular leaf spot (ALS) resistance. Therefore, this study was carried out to characterise the ALS pathogen (Phaeoisariopsis griseola) (Sacc.) into different pathotypes. Forty-two isolates of $P$. griseola were collected from different bean growing areas of western Kenya and characterized into six pathotypes (63:11, 30:26, 33:23, 63:7, 31:10 and 63:63) by use of 12 differential cultivars. Advanced lines and commercial varieties obtained from KALRO-Kakamega were separately inoculated with six pathotypes of P. griseola and evaluated for disease reaction in the screenhouse. A screening trial of Mesoamerican and Andean bean genotypes showed that two varieties were tolerant (disease scores 1 to 3), fourteen varieties were moderately resistant (scores 4 to 6) and four varieties were susceptible (7 to 9). The tolerant varieties were small-seeded, while the susceptible varieties were mostly large-seeded.
\end{abstract}

Keywords: Beans, Pathotypes, Phaeoisariopsis griseola, Severity

\section{Introduction}

Common bean (Phaseolus vulgaris) is an important crop in the daily diet of more than 300 million people worldwide [1]. Half of the world use it for direct consumption this including Eastern and Southern Africa where it's estimated to be cultivated in over four million ha of land [2]. It is the most widely grown pulse, second only to maize as a food crop and a major source of food security in East Africa, including Kenya [3], [4], [5]. Per capita consumption of beans may vary from country to country and region to region, within a country, however generally there is often a higher consumption of bean among low income families both in rural and urban areas [6]. In Kenya, per capita consumption is estimated at $14 \mathrm{~kg}$ per year, but can be as high as $66 \mathrm{~kg}$ per year in western Kenya [7], [8].

Bean yields in Kenya have remained low on-farm with an average yield of $585 \mathrm{~kg} / \mathrm{ha}$ compared to Ethiopia and Rwanda with yields of $1588 \mathrm{~kg} / \mathrm{ha}$ and $913 \mathrm{~kg} / \mathrm{ha}$ respectively [9]. The low bean yield in the region is attributed to a number of factors, among them diseases and use of low yielding disease susceptible varieties [10], [11]. Among the diseases, ALS is a major biotic constraint of bean production in western Kenya.

Several techniques have been used to study the distribution 
and variability of fungi; some of them include; disease surveys, differential cultivars and molecular techniques [12], [13]. Characterisation based on differential cultivars and amplified fragment length polymorphism (AFLP) have revealed high levels of pathogenic and genetic variation in $P$. griseola [14], [15], [16], [17]. In Kenya, forty-four physiological races of $P$. griseola have so far been identified [17]. P. griseola virulence is assessed based on reaction of isolates on a standard differential set of 12 common bean cultivars proposed by CIAT [18], and divided into two sets (Mesoamerican and Andean), with six cultivars each. In this technique, a binary system based on the position of each cultivar within the series is used to define the virulence level of isolates under study [19]. Use of differential cultivars generates a true picture of virulence structure and reveals the pathogen properties related to host selection effect on the pathogen population [13].

Though, ALS has been identified to occur in Kenya, the pathotype variability of the fungus in western Kenya remains unknown and probably as a consequence of this, there is hardly any commercial cultivar either tolerant or resistance which has been developed. In addition, farmers in western Kenya usually tend to use their own seeds from the previous season or supplement their seed requirements with purchases from informal markets, coupled with continuous cropping [20], [21], [22]. This serves as primary inoculum foci for the development and spread of ALS disease. Therefore, a study to understand the variability of the pathogen and test existing bean lines for resistance to isolates form western Kenya is an important intervention in developing bean varieties which are resistant or tolerant against ALS in western Kenya.

\section{Materials and Methods}

\subsection{Collection of Phaeoisariopsis griseola (Sacc.) Isolates}

Isolates of Phaeoisariopsis griseola (Sacc.) were obtained from naturally infected bean leaves collected from the different AEZs surveyed. The samples were collected from diseased bean leaves of different varieties in order to capture a wider representation of pathogen diversity. The samples were stored in paper envelopes and labelled with the host variety name and the zone where the isolate was collected. The collected leaf samples were arranged in between absorbent newspapers and pressed carefully to absorb the moisture and distribute pressure evenly across the samples to keep them intact to avoid any breakage. The samples were then, taken to the laboratory for isolation of the pathogen.

\subsection{Isolation of Phaeoisariopsis griseola (Sacc.) and Inoculum Preparation}

Infected leaves were incubated to induce sporulation in a sterile moist chamber. Using a dissecting microscope, wellsporulating lesions were selected and conidia were picked using a tiny piece of agar placed at the tip of a sterile mounted needle. The conidia were transferred to a drop of sterile distilled water on a microscope slide and the suspension was stirred and streaked onto water agar plates using a sterile wire loop. The plates were incubated at $24^{\circ} \mathrm{C}$ in a non-illuminated incubator until conidia germinated. The germinating conidia were monitored using a dissecting microscope. An agar block with a single germinating conidium was removed and transferred onto Potato dextrose agar (PDA) to obtain monosporic cultures for each isolate. Inoculated plates were incubated at $24^{\circ} \mathrm{C}$ for 14 days. Inoculum was prepared by adding $10 \mathrm{ml}$ of sterile distilled water to each plate and scraping the surface of the culture. The spore suspension obtained was filtered through a sieve to remove the mycelial mass. Spore concentration in the inoculums was estimated using a haemocytometer and adjusted to a final concentration of $2 \times 10^{4}$ conidia ml-1 using sterile distilled water.

\subsection{Inoculation and Pathotype Determination}

In order to determine the pathotype of each isolate a set of 12 differential cultivars consisting of six Andean (Don Timoteo, G 11796, Bolon Bayo, Montcalm, Amendoin, G 5686) and six Middle American (Pan 72, G 2858, Flor de Mayo, Mexico 54, BAT 332, Cornell 49-242) were used (Table 1).

Table 1. Characteristics of the common bean differential cultivars used to characterise Phaeoisariopsis griseola (Sacc.) and the binary values were used to assign isolates to pathotypes.

\begin{tabular}{llll}
\hline Differential cultivar & Notation $^{\mathbf{a}}$ & Seed size $^{\mathbf{b}}$ & Gene pool $^{\text {B }}$ \\
\hline Don Timoteo & $\mathrm{A}$ & $\mathrm{L}$ & Andean \\
G 11796 & $\mathrm{B}$ & $\mathrm{L}$ & Andean \\
Bolon Bayo & $\mathrm{C}$ & $\mathrm{L}$ & Andean \\
Montcalm & $\mathrm{D}$ & $\mathrm{L}$ & Andean \\
Amendoin & $\mathrm{E}$ & $\mathrm{L}$ & Andean \\
G 5686 & $\mathrm{F}$ & $\mathrm{L}$ & Andean \\
PAN 72 & $\mathrm{G}$ & $\mathrm{S}$ & Middle American \\
G 2858 & $\mathrm{H}$ & $\mathrm{M}$ & Middle American \\
Flor de Mayo & $\mathrm{I}$ & $\mathrm{S}$ & Middle American \\
Mexico 54 & $\mathrm{J}$ & $\mathrm{M}$ & Middle American \\
BAT 332 & $\mathrm{K}$ & $\mathrm{S}$ & Middle American \\
Cornell 49242 & $\mathrm{~L}$ & $\mathrm{~S}$ & Middle American \\
\hline
\end{tabular}

Notation $^{\mathrm{a}}$ : Differential cultivars

Seed size ${ }^{\text {b}}$ : L $=$ Large, $M=$ medium, $S=$ Small 
The seeds were potted in sterile soil mixture composed of loam soil, sand and manure in the ratio of $2: 1: 1$. Three seeds of each cultivar were sown per polythene pot and thinned to one plant two weeks after germination to attain proper plant population. Three-week old seedlings were inoculated with Phaeoisariopsis griseola isolates at a concentration of $2 \mathrm{x}$ $10^{4}$ conidia/ml by spraying on the upper and lower side of the leaf until runoff using a hand sprayer. Inoculated plants were maintained in high humidity through frequent mist sprays. Disease scoring was based on the presence $(+)$ or absence $(-)$ of disease symptoms. The pathotypes so far identified were mapped on AEZs to determine the areas where each pathotype occurred.

\subsection{Common Bean Varieties Used}

Twenty common bean varieties (13 advanced lines and 7 commercial varieties) obtained from KALRO- Kakamega were used in this experiment (Table 2). The seeds were obtained from KALRO-Kakamega because they offer certified clean seeds which was necessary for the experiment to avoid any seed source inoculum which could have altered results as the disease has been reported by [23] to be seed borne.

Some of the important characteristics of these bean varieties are presented in Table 2 below.

Table 2. Characteristics of bean varieties evaluated against Phaeoisariopsis griseola (Sacc.).

\begin{tabular}{|c|c|c|c|c|}
\hline Variety & Origin & Seed size & Seed colour & Growth Habit \\
\hline KKR IL05/RED 13 & Advanced line & $\mathrm{M}$ & Red & II \\
\hline KKR IL05/RED 16 & 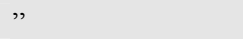 & M & Red & II \\
\hline KKR IL05/RED 20 & " & $\mathrm{L}$ & Red & II \\
\hline KKR IL05/CAL 33 & , & $\mathrm{L}$ & Red mottle & II \\
\hline KKR IL05/RED 40 & , & $\mathrm{S}$ & Red & II \\
\hline KKR IL05/CAL139A & $"$ & $\mathrm{~L}$ & Purplish & II \\
\hline KKR IL05/CAL194 & $"$ & M & Red mottled & II \\
\hline KK 071 & $"$ & $\mathrm{~L}$ & Red kidney & I \\
\hline KK 072 & " & $\mathrm{L}$ & Red kidney & I \\
\hline KK 15 & , & M & Black & III \\
\hline KK 8 & " & M & Red mottled & I \\
\hline KK 20 & " & $\mathrm{M}$ & Red & II \\
\hline KK 22 & Commercial variety & $\mathrm{S}$ & Dark Red & II \\
\hline GLP-2 & Commercial variety & $\mathrm{L}$ & Red mottled & I \\
\hline GLP-24 & Commercial variety & $\mathrm{L}$ & Red & I \\
\hline GLP-1127 & Commercial variety & $\mathrm{L}$ & Grey & II \\
\hline Mwezi mbili & Commercial variety & $\mathrm{L}$ & Cream striped & II \\
\hline
\end{tabular}

Seed size: $\mathrm{L}=$ large; $\mathrm{M}=$ medium; $\mathrm{S}=$ small

Growth habit: I determinate bush, II indeterminate bush, III indeterminate prostrate

\subsection{Isolates Used}

Six isolates $(63: 11,30: 26,33: 23,63: 7,31: 10$ and 63:63) were used in this study to evaluate the resistance of the common bean to Phaeoisariopsis griseola (Sacc.) pathogen. The isolates were obtained after characterisation by use of differential cultivars as shown in Table 3.

\subsection{Planting and Scoring of Disease Severity}

Two seeds of each variety were sown in polythene pots and thinned to one plant two weeks after germination to have proper plant population. Each variety was inoculated separately with each of the six Phaeoisariopsis griseola (Sacc.) pathotypes as described in section 3.2.3, when the seedlings were three-weeks-old [24] and monitored for disease reaction. The experiment was a factorial testing two factors viz: variety and severity. Twenty varieties under inoculation and uninoculation treatments repeated three times making it a total of one hundred and twenty treatments laid in a complete randomized design.

Disease symptoms on the inoculated plants were evaluated using a CIAT 1-9 visual scale [25] for 21 days at an interval of three days, as follows: 1, with no visible disease symptoms; 3 , presence of a few small non-sporulating lesions that cover approximately $2 \%$ of the leaf surface; 5 , with several small lesions with limited sporulation and covering approximately $5 \%$ of leaf surface; 7 , with abundant and generally large sporulating lesions covering approximately $10 \%$ of leaf surface and associated with chlorosis and necrosis; 9 , as $25 \%$ or more of leaf surface with large sporulating and often coalescing lesions, resulting in severe and premature defoliation.

\subsection{Statistical Analysis}

Data was subjected to analysis of variance using SPSS version 22, at $(\mathrm{P}<0.05)$ and means separated using least significant difference (LSD) at $5 \%$ probability level. The mean scores were used to partition disease severity of different ALS isolates on bean genotypes into resistant, moderately resistant and susceptible. 


\section{Results}

\subsection{Pathotype Determination}

The isolates of Phaeoisariopsis griseola had different patterns of virulence when inoculated on 12 differential bean cultivars. Most of the isolates were pathogenic to both Andean and Middle American differentials. The isolates were characterised into six pathotypes; 63:11, 30:26, 33:23, 63:7, 31:10 and 63:63 (Table 3).

Table 3. Response of 12 differentials to P.griseola isolates.

\begin{tabular}{|c|c|c|c|c|c|c|c|c|c|c|c|c|c|c|}
\hline \multicolumn{7}{|c|}{ Andean } & \multicolumn{6}{|c|}{ Mesoamerican } & \multirow{2}{*}{ Pathotype } & \multirow{2}{*}{ No. of isolates } \\
\hline AEZ & $\mathbf{A}$ & B & $\mathbf{C}$ & D & $\mathbf{E}$ & $\mathbf{F}$ & $\mathbf{G}$ & $\mathbf{H}$ & I & $\mathbf{J}$ & $\mathbf{K}$ & $\mathbf{L}$ & & \\
\hline & 1 & 2 & 4 & 8 & 16 & 32 & 1 & 2 & 4 & 8 & 16 & 32 & & \\
\hline \multirow[t]{3}{*}{ LH1 } & - & + & + & + & + & - & - & + & - & + & + & - & $30: 26$ & 4 \\
\hline & - & + & + & + & + & - & + & + & - & - & + & - & $30: 23$ & 2 \\
\hline & + & + & + & + & + & + & + & + & + & + & + & + & $63: 63$ & 1 \\
\hline \multirow[t]{3}{*}{ LM1 } & + & + & + & + & + & + & + & + & - & + & - & - & $63: 11$ & 4 \\
\hline & - & + & + & + & + & - & - & + & - & + & + & - & $30: 26$ & 1 \\
\hline & + & + & + & + & + & + & + & + & + & - & - & - & $63: 7$ & 2 \\
\hline \multirow[t]{4}{*}{ LM2 } & + & + & + & + & + & - & - & + & - & + & - & - & $31: 10$ & 4 \\
\hline & + & + & + & + & + & + & + & + & - & + & - & - & $63: 11$ & 1 \\
\hline & + & + & + & + & + & + & + & + & + & + & + & + & $63: 63$ & 1 \\
\hline & - & + & + & + & + & - & - & + & - & + & + & - & $30: 26$ & 1 \\
\hline \multirow[t]{5}{*}{ LM3 } & - & + & + & + & + & - & - & + & - & + & + & - & $30: 26$ & 1 \\
\hline & + & + & + & + & + & + & + & + & + & - & - & - & $63: 7$ & 2 \\
\hline & + & + & + & + & + & + & + & + & + & + & + & & $63: 63$ & 1 \\
\hline & + & + & + & + & + & & - & + & - & + & - & - & $31: 10$ & 2 \\
\hline & + & + & + & + & + & + & + & + & + & - & - & - & $63: 11$ & 1 \\
\hline \multirow[t]{3}{*}{ LM4 } & - & + & + & + & + & - & + & + & + & - & + & - & $30: 23$ & 3 \\
\hline & - & + & + & + & + & - & - & + & - & + & + & - & $30: 26$ & 3 \\
\hline & + & + & + & + & + & - & - & + & - & + & - & - & $31: 10$ & 1 \\
\hline \multirow[t]{2}{*}{ UM1 } & + & + & + & + & + & + & + & + & - & + & - & - & $63: 11$ & 3 \\
\hline & + & + & + & + & + & + & + & + & + & + & + & + & $63: 63$ & 4 \\
\hline Total & & & & & & & & & & & & & & 42 \\
\hline
\end{tabular}

Andean cultivars: (a) Don Timoteo; (b) G 11796; (c) Bloom Bayo; (d) Montcalm; (e) Amendoin; (f) G 5686. Middle American cultivars: (g) Pan 72; (h) G 2858; (i) Flor de Mayo; (j) Mexico 54; (k) BAT 332; (l) Cornell 49-242. Pathotype designation is based on the sum (binary values) of bean cultivars (+), Compatible reaction; (-), Incompatible reaction (as per Pastor-Corrales and Jara, (1995)

\subsection{Mapping of Identified Isolates Over AEZs}

GLP-2 and GLP-585 were found to be infected by all the by pathotypes in all the AEZs surveyed as presented in Table 4 below. The most prevalent pathotypes across AEZs were 63:63 and 30:26. KK15 was to be infected by pathotype 63:63 in UM1, LM1 and LM2. Pathotype 63:7 infected GLP-
585 and KK8 only in LM1, while pathotypes 63:11 and 31:10 infected GLP-2, GLP-585, Zaire, KAT X56 and Punda in UM1, LM1 and LM3. Pathotype 30:26 infected GLP-2, Zaire and Punda in LM4 and LH1, while pathotype 30:23 infected GLP-585 only in LM4 and LH1 (Table 4).

Table 4. Isolates of Phaeoisariopsis griseola (Sacc.).

\begin{tabular}{|c|c|c|c|c|c|c|c|c|}
\hline & VARIET & & & & & & & \\
\hline AEZs & GLP-2 & GLP-585 & KK8 & KK15 & Zaire & KAT X56 & Punda & No. of Isolates \\
\hline LH1 & $30: 26(2)$ & $30: 23(2)$ & $63: 63$ & & & & $30: 26(2)$ & 7 \\
\hline UM1 & $63: 11$ & $63: 11(2)$ & $63: 63$ & $63: 63(2)$ & & & $63: 63$ & 7 \\
\hline LM1 & $30: 26$ & $63: 7$ & $63: 7$ & $63: 63$ & $63: 11$ & $63: 11$ & $63: 11$ & 7 \\
\hline LM2 & $31: 10$ & $31: 10$ & $63: 8$ & $63: 63$ & $31: 10$ & $31: 10$ & $31: 10$ & 7 \\
\hline LM3 & $30: 26$ & $63: 7$ & $63: 7$ & & $63: 11$ & $31: 10(2)$ & $63: 63$ & 7 \\
\hline LM4 & $30: 26(2)$ & $30: 23(3)$ & & & $30: 26$ & $31: 10$ & & 7 \\
\hline
\end{tabular}

\subsection{Symptoms of ALS Observed in the Screen House}

For all the six pathotypes, the symptoms developed 10-15 days after inoculation. The first symptoms developed on the primary leaves as circular lesions which enlarged and attained larger sizes and in some lines lesions coalesced, while in some bean varieties there was extensive chlorosis on the leaves e.g. GLP-1127 inoculated with race 63-63 (Fig. 1).

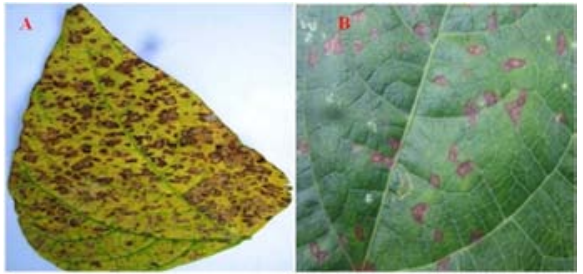

Figure 1. Symptoms of ALS on GLP-1127 leaves; A-Intensive chlorosis, BLarge coalescing lesions of ALS. 


\subsection{Reaction of Common Bean Varieties to Phaeoisariopsis Griseola Pathotypes}

The reaction of bean varieties to different pathotypes of $P$. griseola is presented in Table 5 below. Pathotype 63:63 was

Table 5. Mean reaction of bean varieties to Phaeoisariopsis griseola pathotypes.

\begin{tabular}{|c|c|c|c|c|c|c|}
\hline Genotypes & $33: 23$ & 31:10 & $30: 26$ & $63: 7$ & 63:11 & $63: 63$ \\
\hline KKRIL05/Red 40 & 3 & 3 & 2 & 4 & 3 & 6 \\
\hline KKRIL05/Red 13 & 4 & 5 & 3 & 4 & 4 & 6 \\
\hline KKRIL05/Red 16 & 4 & 4 & 6 & 3 & 6 & 7 \\
\hline KKRIL05/Red 20 & 6 & 6 & 6 & 7 & 5 & 8 \\
\hline Mwezi mbili & 5 & 5 & 7 & 6 & 7 & 8 \\
\hline GLP-585 & 4 & 5 & 3 & 5 & 5 & 4 \\
\hline KK22 & 5 & 5 & 7 & 5 & 6 & 8 \\
\hline KK06/110 & 4 & 3 & 5 & 5 & 5 & 7 \\
\hline KKRIL05/Cal 33 & 6 & 6 & 6 & 6 & 6 & 8 \\
\hline KKRIL05/Cal 139A & 6 & 6 & 7 & 6 & 8 & 7 \\
\hline KK8 & 6 & 4 & 4 & 5 & 6 & 9 \\
\hline GLP-2 & 4 & 7 & 6 & 5 & 6 & 7 \\
\hline KK071 & 5 & 7 & 5 & 6 & 7 & 8 \\
\hline KK20 & 7 & 6 & 6 & 7 & 5 & 8 \\
\hline GLP-1127 & 6 & 7 & 7 & 5 & 8 & 8 \\
\hline GLPX-92 & 6 & 7 & 8 & 8 & 8 & 8 \\
\hline KK15 & 7 & 7 & 7 & 7 & 8 & 8 \\
\hline Mean & 4.70 & 5.13 & 5.20 & 5.18 & 5.53 & 7.05 \\
\hline SE & 0.24 & 0.27 & 0.29 & 0.25 & 0.26 & 0.23 \\
\hline
\end{tabular}

For the varieties, KKR IL05/Red 40 was tolerant in most of the pathotypes with a mean reaction of 3 except in pathotype 63:63 where it had a mean score of 6. GLP-24, KKR IL05/Cal 194, KKR IL05/Cal 33, GLP-2, GLP-585, KK 071, KK06/110, KK20, KK 072, KK 22, KK 8, KKR IL05/ Red 13, KKR IL05/Red 16, KKR IL05/Red 20 were moderately resistant with a mean reaction of 4-6; whereas Cal 139, GLP2, KK071, KK20, KK072, GLP24, GLP-1127, GLP-X92 and KK 15 were susceptible with mean reaction of 7-9.

\section{Discussion}

The reaction of 42 Phaeoisariopsis griseola isolates on standard bean differential cultivars showed the existence of pathogenic variability of ALS pathogen. The isolates of Phaeoisariopsis griseola were characterised into six pathotypes. Similar findings have been reported by [15] and [26] who observed, on average, the occurrence of one pathotype for each two and seven isolates respectively. Studies by [15] and [27] found larger variability than those conducted by [26] probably due to the great diversity of the sampled places and to the hosts from both gene pools (Mesoamerican and Andean). This was clearly exhibited in the findings as six AEZs within western Kenya were covered. This explains the variability of the Phaeoisariopsis griseola due to diversity of the sampled places within the region. Likewise, [17] verified the existence of high pathogenic variation of Phaeoisariopsis griseola isolates in Kenya. She reported existence of forty-four physiological races of Phaeoisariopsis griseola. The wide distribution of the more virulent with a mean severity of 7 , followed by $63: 11$ with a mean severity of 6 , whereas 30:26, 33:23, 63:7and 31:10 were less virulent with a mean severity of 5 . variability of Phaeoisariopsis griseola was confirmed to occur worldwide. [28] verified the occurrence of 120 pathotypes in 22 countries and, among the pathotypes identified, 71 were discovered specifically in Brazil.

This large pathogenic variation could have been associated with mutation, recombination and migration [29]. Also, specialisation in host-pathogen interactions, control measures or more general environmental constraints may singly or interact in combination to give raise to new pathotypes leading to high levels of diversity in the pathogen [15].

The study also identified pathotype 63:63 as the highly virulent compared to the other pathotypes. Though reported by [17] in Embu, it was reported for the first time in western Kenya in this study. [30] reported the pathotype as the most virulent in other countries such as Honduras and Nicaragua and Brazil.

Furthermore, in western Kenya, small and large-seeded bean cultivars are widely grown in adjacent fields and farmers have been reported to grow up to eight different cultivars on the same farm [21], [22], [17]. This farming practice may have contributed to the development of new pathotypes as isolates evolve to infect the different bean varieties. Phaeoisariopsis griseola is known to be seed-borne [30] and the high movement of bean germplasm from one region to another, even across national borders, may also lead to the introduction of new pathotypes through contaminated seed that led to high pathogenic variation observed in western Kenya. Furthermore, due to high cost of certified seed, farmers source seed from fellow farmers or informal markets whose supplies comes from different parts of the 
country and even from neighbouring countries. These findings are in agreement with [31] who reported that most farmers in Africa practicing bean production mainly obtain their seeds from informal channels such as farm saved seeds to avoid overspending. This adversely implies farm saved seeds play a major role in harbouring more infected seeds leading to spread of seed borne diseases contributing to reduction in yield [32]. Such a seed system is liable to transmission of different Phaeoisariopsis griseola races across bean production areas. However, [33] demonstrated that farmers in Uganda produce and save own pure seeds for the next cropping season through proper seed production system consequently reducing the spread of seed borne diseases.

The study also found out that, some common bean varieties like GLP-2, GLP-585, KAT X56 and Punda were infected by more than one pathotype. This could be attributed to multiple leaf infections by different pathotypes which can lead to parasexual recombination [29], hence giving rise to more than one pathotypes present on a single plant.

The lesions induced by Phaeoisariopsis griseola pathotypes were characteristically circular at early stages but with time they attained larger sizes of angular shape. This conformed with [34] who found that on the primary leaves, the lesions tend to be circular but on the trifoliates, the spots were delimited by veins and vein lets, giving them a characteristic angular shape.

All the fourteen moderately resistant cultivars to Phaeoisariopsis griseola were small seeded suggesting that small seeded size derived mainly from a cross of GLP585 and KK22 that are Meso-American types. This reaction suggests that most of the pathotypes may be of Andean type as reported in Africa [24] and therefore less severe on genotypes derived from Meso-American gene pools. These results are also consistent with the report by [19] who observed that of the 19 bean accessions that were intermediate or resistant to ALS, 15 were small or mediumsized while only four were large-seeded. These results are also in support of earlier observations from [35] that the resistant bean accessions, often without any visible ALS symptoms, are the small-seeded varieties of Middle American origin. [34] also reported that most of the known sources of ALS resistance are evidently small-seeded bean varieties and that very little resistance exists among the popular large-seeded varieties in Southern Africa.

\section{Conclusion}

The use of standard bean differential cultivars has revealed the existence of pathogenic variability of ALS pathogen in western Kenya with pathotype 63:63 being the most virulent and frequent across the AEZs sampled. Also, most moderately resistant cultivars to Phaeoisariopsis griseola are small seeded suggesting that small seeded size were derived mainly from a cross of GLP585 and KK22 which are MesoAmerican types. Therefore, durable resistance will be required to manage the disease due to the variation exhibited by this pathogen.

\section{Abbreviations}

$\begin{array}{ll}\text { ALS } & \text { Angular Leaf Spot } \\ \text { ANOVA } & \text { Analysis of variance } \\ \text { AEZs } & \text { Agro Ecological Zones } \\ \text { BRR } & \text { Bean Root Rot } \\ \text { CIAT } & \text { Centre International Agricultural Tropical } \\ \text { FAO } & \text { Food and Agriculture Organization } \\ \text { FAOSTAT } & \text { Food and Agricultural Organization Statistics } \\ \text { GOK } & \text { Government of Kenya } \\ \text { KALRO } & \text { Kenya Agricultural and Livestock Research } \\ \text { LH } & \text { Organisation } \\ \text { LM } & \text { Lower Highlands } \\ \text { MOA } & \text { Lower Midlands } \\ \text { UM } & \text { Ministry of Agriculture }\end{array}$

\section{References}

[1] Hadi, H., Kazem, G. G., Farrokh, K., Mostafa, V. and Mohammed, S. 2006. Response of common bean (Phaeseolus vulgaris L.) to different levels of shade. J. Argon. 5: 595-599.

[2] Beebe, E. S., Rao, M. I., Devi, J. M., and Polania, J. 2014. Common beans, biodiversity, and multiple stresses: challenges of drought resistance in tropical soils. Crop and Pasture Science 65(7): 667-675.

[3] Mauyo, L.W., Okalebo, J. R., Kirby, R. A., Buruchara, R., M., Ugen, M. A. and Musebe, R. O. 2007. Legal and institutional constraints to Kenya-Uganda cross-border bean marketing. African Journal of Agricultural Research 2: 578582 .

[4] Kiiya, W. W. 1997. A review of production practices and constraints for grain legumes with special emphasis on dry beans. In: Rees, D. J. and C. Nkonge (eds). A review of agricultural practices and constraints in the North Rift Valley Province, Kitale, Kenya. 26 - 28 Sept. 1995: 60-83.

[5] Muasya, R. M. 2001. Crop physiological analysis of seed quality variation in common Beans (Phaseolus vulgaris L.)," $\mathrm{Ph} . \mathrm{D}$. Thesis, Wageningen University, the Netherlands.

[6] Hillocks, R. J., Madata, C. S., Chirwa, R., Minja, E. M. and Msolla, S. 2006. Phaseolus bean improvement in Tanzania 1959-2005. Euphyta 150: 225-231.

[7] Spilsbury, J., Jagwe, J. and Wanda, K. 2004. Evaluating the marketing opportunities for beans and its products in the principle beans growing countries of ASARECA, draft regional report compiled by International Institute of Tropical Agriculture and Food net.

[8] Buruchara, R., Chirwa, R., Sperling, L., Mukankus, I. C., Rubyogo, J. C., Muthoni, R. and Abang, M. M. 2011. Development and delivery of bean varieties in africa: The panAfrica bean research alliance (PABRA) model. African Crop Science Journal 19 (4): 227-245.

[9] FAOSTAT. 2014. Food and agriculture organization at http://faostat.fao.org. 
[10] Nderitu, J. N. and Otsyula, R. M. 1997. Survey of bean root rots, bean stem maggot, soil fertility and management practices in farmer's fields. Annual report RRC Kakamega. 32pp.

[11] Otsyula, R. M., Ajanga, S. I., Buruchara, R. A. and Wortman, C. S. 1998. Developments of an integrated bean root rot control strategy for western Kenya. African Crop Science Journal 6: 61-67.

[12] Sartorato, A. 2004. Pathogenic variability and genetic diversity of Phaeoisariopsis griseola isolates from two counties in the State of Goias, Brazil. J Phytopathol 152: 385 390 .

[13] Sebastian, A., Stenglein, I., Pedro, A. and Balatti, A. 2006. Genetic diversity of Phaeoisariopsis griseola in Argentina as revealed by pathogenic and molecular markers. Physiological and Molecular Plant Pathology 68: 158-167.

[14] Guzman, P., Gepts, P., Temple, S., Mkandawire, A. B. C. and Gilbertson, R. L. 1999. Detection and differentiation of Phaeoisariopsis griseola isolates with the polymerase chain reaction and group-specific primers. Plant Disease 83: 37-42.

[15] Mahuku, G. S., Henriquez, M. A., Munoz, J. And Buruchara, R. A. 2002a. Molecular markers dispute the existence of the Afro-Andean group of the bean angular leaf spot pathogen. Phaeoisariopsis griseola. Phytopathology 92: 580-589.

[16] Mahuku, G. S., Jara, C., Cuasquer, J. B. and Castellanos, G. 2002b. Genetic variability within Phaeoisariopsis griseola from Central America and its implication for resistance breeding of common bean. Plant Patholology 51: 594-604.

[17] Wagara, I. N., Mwang'ombe, A. W., Kimenju, J. W. and Buruchara, R. A. 2005. Virulence, variability and physiological races of the angular leaf spot pathogen. Phaeoisariopsis griseola in Kenya. African Plant Protection 11: 23-31.

[18] Pastor-Corrales, M. A. and Jara, C. E., 1995. La evolución de Phaeoisariopsis griseola con el frijol común en América Latina. Fitopatología Colombiana 19: 15-24.

[19] Pastor-Corrales, M. A, Jara, C. and Singh, S. P. 1998 Pathogenic variation in sources of and breeding for resistance to Phaeoisariopsis griseola causing angular leaf spot in common bean. Euphytica 103: 161-171.

[20] Wakahiu, M. W. 2000. Assessment of bean (Phaseolus $\begin{array}{llll}\text { vulgaris } & \text { L.) cv-Rosecoco GLP-2 seed for }\end{array}$ infection/contamination by Macrophomina phaseolina and its implication on disease incidence and severity. M.Sc. Thesis, University of Nairobi, pp: 127.

[21] Mwaniki, A. W. 2002. Assessment of bean production constraints and seed quality and health of improved common bean seed. M.Sc. Thesis, University of Nairobi, pp: 113.

[22] Wachenje, C. W. 2002. Bean production constraints, bean seed quality and effect of intercropping on floury leaf spot disease and yields in Taita Taveta district, Kenya. MSc thesis, University of Nairobi, Kenya.

[23] Allen, D. J., Ampofo, K. K. O. and Wortmann, C. S. 1996. Pest, diseases and nutritional disorders of the common bean in Africa: A field guide. CIAT publication No. 260: 53-54.

[24] Wagara I. N, Mwang'ombe A. W, Kimenju J. W, Buruchara R. A, Jamnadass R and Majiwa P. A. O 2004. Genetic diversity of Phaeoisariopsis griseola in Kenya as revealed by AFLP and group-specific primers. Journal of Phytopathology 152: 1-8.

[25] Van Schoonhoven, A. and Pastor-Corrales, M. A. 1987. Standard system for the evaluation of bean germplasm. C. I. A. T., Cali, Colombia.

[26] Sartorato A. 2002. Identification of Phaeoisariopsis griseola pathotypes from five states in Brazil. Fitopatol Bras 27:78-81.

[27] Orozco, S. and Araya, C. M. 2005. Variabilidade patogenica de Phaeoisariopsis griseola na Costa Rica. Fitopatol Bras 30: 589-593.

[28] Jara, C., Castellano, G., Mahuku, G. 2001. Estado actual y proyeccio' n de la investigacio' n relacionada com la mancha angular del frijol (Phaeoisariopsis griseola). Fitopatol Colomb 25: 1-6.

[29] Leung H, Nelson R. J, Leach J. E. 1993. Population structure of plant pathogenic fungi \& bacteria. Advances in plant patholpgy.10.157-205.

[30] Sartorato, A., Nietsche, S., Barros, E. G. and Moreira, M. A. 2000. RAPD and SCAR markers linked to resistance gene to angular leaf spot in common beans. Fitopatol Bras 25:637642 .

[31] Oshone K., Gebeyehu S. and K. Tesfaye. 2014. Assessment of common beans (Phaseolus vulgaris L.) seed quality produced under different cropping system by small holder farmers in eastern Ethiopia. African Journal of Food, Agriculture Nutrition and Development, 14: (1) 8566-8584.

[32] Dube, E., Sibiya, J. and Fanadzo, M. 2014. Early planting and hand sorting effectively controls seed-borne fungi in farmretained bean seed. South Africa Journal of Science, 110:1112.

[33] Njuki, S. K. and Andersson, P. 2014. Farmer participatory evaluation of bean (Phaseolus vulgaris L) varieties for seed production in Teso-karamoja Sub-region, Uganda. International Journal of Research in Agriculture and Food Sciences, 3(2): 13-27.

[34] Liebenberg, M. M. and Pretorius, Z. A. 1997. A review of angular leaf spot of common bean (Phaseolus vulgaris L.). African Plant Protection 3: 81-106.

[35] CIAT.1996. Bean program annual report, 39-49. CIAT, Cali, Colombia. 